Volume 10 Nomor 1, November 2018, p.026-037

Faculty of Law, Universitas Kristen Maranatha

ISSN: 2085-9945 I e-ISSN: 2579-3520

Nationally Accredited Journal by SINTA

\title{
Urgensi Peran dan Fungsi Perbankan dalam Meningkatkan Usaha, Mikro, Kecil dan Menengah di Indonesia
}

\author{
M. Agung Dharmajaya \\ Universitas Jenderal Soedirman Purwokerto \\ agungdharmajaya456@gmail.com
}

Submitted: 2018-09-29; Reviewed: 2018-11-22; Accepted: 2018-11-26

\begin{abstract}
.
Micro, Small and Medium Enterprises (UMKM) are an economic stimulus for a developing country like Indonesia, most essentially in a condition of economic crises. Micro, Small and Medium Enterprises hold a crucial role in society to grow its economic activities. Regarding the context, financial supports from banks to micro, small and medium enterprises (UMKM) become crucial that they help grow the economic stimulus. The aim of this research is to investigate roles and functions of banking sector to help mature the micro, small and medium enterprises in Indonesia. In addition, the research is applying a descriptive qualitative method.

Banking sector contribution in growth of micro, small and medium enterprises (UMKM) has been a collective focus among governance, banking, and micro, small and medium enterprises community. Many regulations have been made to support easier distribution of funding to UMKM from banking institutions through Central Bank Regulations. However, an issue appeared in relation to the roles and functions of banking institutions towards UMKM regarding credits channeling for their operational purposes. The problem occurred when NPL is over 3\% which sending a message to banking institutions to be more cautious in giving credits to micro, small and medium enterprise (UMKM). The research has found, based on the context, the importance of synergies among all micro, small and medium enterprises subjects in maximizing banking roles and functions to improve quality and quantity of micro, small and medium enterprise (UMKM) in Indonesia.
\end{abstract}

Keywords: Banking; Credit; Micro-Smal, Medium Enterprises.

\section{PENDAHULUAN}

Usaha Mikro Kecil dan Menengah atau yang biasa disebut dengan UMKM pada dasarnya merupakan salah satu kekuatan pendorong terdepan dalam pembangunan 
ekonomi di Indonesia, adapun hal ini didasarkan pada peranan UMKM yang cukup signifikan khususnya terkait daya tahan ekonomi sampai dengan penyerapan tenaga kerja. Sebagai contoh, ketika krisis ekonomi tahun 1997-1998 menimpa Indonesia, hanya sektor UMKM yang mampu tetap bertahan dari ketidakstabilan ekonomi nasional. Berdasarkan data Badan Pusat Stastistik yang telah dirilis, bahwa keadaan tersebut (jumlah UMKM) pasca krisis ekonomi tidak berkurang, bahkan mengalami pertumbuhan kuantitas yang meningkat, UMKM mampu menyerap hingga 107 juta tenaga kerja sampai tahun 2012 dari sebelumnya 56 juta pada tahun $1997 .{ }^{1}$

Realitas tersebut mendeskripsikan bahwa UMKM merupakan usaha yang produktif dan memiliki potensi untuk dikembangkan sebagai faktor pendukung perkembangan ekonomi makro dan mikro di Indonesia. Pengalaman krisis ekonomi telah menyadarkan banyak pihak khususnya pemerintah Indonesia untuk memberikan kebijakan-kebijakan yang pro terhadap UMKM, sekaligus berusaha memberikan porsi yang lebih besar terhadap keberlangsungan bisnis usaha skala mikro, kecil, dan menengah melalui berbagai kebijakan, termasuk didalamnya kebijakan dalam meningkatkan kuantitas UMKM dan melakukan pemberdayaan UMKM sesuai dengan karakteristik kebutuhan usaha.

Sebagai bentuk dukungan, Pemerintah telah mengeluarkan kebijakan terkait UMKM sebagaimanaa dikeluarkannya Undang-Undang Nomor 20 Tahun 2008 tentang Usaha Mikro, Kecil dan Menengah (UMKM). Adapun tujuan dari regulasi tersebut yaitu untuk menumbuhkan dan mengembangkan usahanya dalam rangka membangun perekonomian nasional berdasarkan demokrasi ekonomi yang berkeadilan. Pada kebijakan terebut pemerintah membagi kriteria aset dan omset menjadi 3 (tiga) bagian yaitu:

\section{Tabel 1 Kriteria UMKM}

\begin{tabular}{|c|c|c|}
\hline \multirow{2}{*}{ Keterangan } & Kriteria & \multicolumn{2}{|c|}{ Omset } \\
\cline { 2 - 3 } & Aset & Maksimal. Rp. 500 Juta \\
\hline Usaha Mikro & Maksimal Rp 50 Juta & $\begin{array}{c}>\text { Rp. 500 Juta - Rp. 2,5 } \\
\text { Milyar }\end{array}$ \\
\hline Usaha Kecil & $>$ Rp. 50 Juta - 500 Juta & $\begin{array}{l}>\text { Rp. 2,5 Milyar - Rp. 50 } \\
\text { Milyar }\end{array}$ \\
\hline Usaha Menengah & $\begin{array}{c}>\text { Rp. 500 Juta - Rp. 10 } \\
\text { Milyar }\end{array}$ & \multicolumn{2}{|c|}{} \\
\hline
\end{tabular}

Sumber: www.depkop.go.id

\footnotetext{
${ }^{1}$ Yuli Rahmini Suci, "Perkembangan UMKM (Usaha Mikro Kecil Dan Menengah) di Indonesia",
} Jurnal Ilmiah Cano Ekonomos, Vol. 6 No. 1 Januari 2017, hlm 51. 
Berdasarkan tabel 1, dapat dideskripsikan bahwa pemberdayaan UMKM menjadi hal yang urgensi terkait ketimpangan kepemilikan aset usaha dibandingkan usaha besar. Misalnya, Usaha besar lebih dari Rp. 10 Milyar dan Omset yang lebih dari Rp. 51 Milyar dan usaha mikro yang tidak lebih dari aset Rp 50 Juta dan omset tidak lebih dari Rp. 50 Juta. Pada sisi ini terlihat bahwa sesungguhnya pemberdayan UMKM memiliki ruang lingkup yang luas dan tentunya membutuhkan dukungan dari pemerintah dan jasa perbankan dalam rangka memberdayaan UMKM, bukan saja secara regulasi melainkan turut serta menjawab persoalan UMKM dalam mengoperasionalkan kegiatan usahanya.

Fenomena yang terjadi ketika UMKM masih memiliki beberapa kelemahan klasik dalam meningkatkan kemampuan usaha, adapun kelemahan tersebut meliputi berbagai indikator yang mana salah satu dengan yang lainnya saling berkaitan antara lain; kurangnya kemampuan manajerial dan keterampilan beroperasi dalam mengorganisir, terbatasnya pemasaran, terbatasnya sarana dan prasarana usaha, sifat produk dengan life time pendek, persaingan yang kurang sehat dan desakan ekonomi sehingga mengakibatkan ruang lingkup usaha menjadi sempit dan terbatas serta kurangnya permodalan baik jumlah maupun sumbernya.

Studi yang dilakukan oleh Zain dalam Sri Susilo² mengenai skema pembiayaan perbankan daerah terhadap UMKM di Provinsi Sulawesi Selatan. Hasil studi tersebut antara lain: (1) penyaluran kredit dari perbankan memberlakukan skim yang bersifat general terhadap UMKM, hal ini membuat pengusaha UMKM kesulitan dalam memperoleh kredit perbankan karena alasan persyaratan penjaminan. (2) Akses perolehan permodalan oleh pengusaha UMKM pada umumnya terkendala pada lemahnya sistem administrasi keuangan usaha dan kurangnya jaminan yang bankable, daya saing usaha rendah, dan lemahnya integrasi pembinaan UMKM. (3) Proses pelayanan kredit oleh pihak perbankan oleh perbankan dilihat dari ratarata waktu yang digunakan dalam pengurusan kredit sampai pada pencairan kredit hanya memerlukan waktu yang relatif singkat.

Selanjutnya, studi yang dilakukan oleh Sri Susilo \& Sutarta ${ }^{3}$ menemukan bahwa terbatasnya akses pembiayaan industri kecil terhadap perbankan terutama masalah persyaratan administrasi perkreditan, di mana pada umumnya industri kecil tidak bankable. Bagi industri kecil yang memperoleh fasilitas kredit dari perbankan menyatakan bahwa kredit tersebut sangat bermanfaat bagi pengembangan usaha mereka. Kredit tersebut terutama digunakan untuk investasi yang berkaitan dengan peralatan dan modal usaha, termasuk tempat usaha. Bagi industri kecil yang telah

\footnotetext{
${ }^{2}$ Sri Suslilo. Y, "Peran Perbankan Dalam Pembiayaan Umkm di Provinsi DIY", Jurnal Keuangan dan Perbankan, Vol. 14, No. 3 September 2010, hlm. 469.

${ }^{3}$ Sri Susilo, Y. \& Sutarta, A.E, "Masalah dan Dinamika Industri Kecil Pasca Krisis Ekonomi”, Jurnal Ekonomi Pembangunan, Vol. 9 No. 1, 2004, hlm.65-78.
} 
berhasil maka pihak perbankan datang untuk menawarkan berbagai fasilitas kredit. Sebagian besar responden mengusulkan prosedur untuk memperoleh kredit perbankan agar lebih dipermudah. Studi ini dilakukan terhadap industri kecil di wilayah Surakarta dan Yogyakarta.

Berkaitan dengan masalah terbatasnya permodalan, UMKM membutuhkan dukungan dari lembaga pembiayaan termasuk perbankan. Sebagaimana hasil peneiltian Sri Susilo ${ }^{4}$, menunjukkan akses UMKM terhadap sumber pembiayaan perbankan perlu ditingkatkan, termasuk juga sumber-sumber pembiayaan lain nonperbankan seperti modal ventura dan lembaga penjamin kredit. Dari berbagai hasil studi ternyata akses sebagian besar UMKM terhadap perbankan masih terbatas. Permasalahan ini terkait dengan profil dari debitur-debitur usaha skala mikro yang kurang atau bahkan tidak bankable atau tidak memenuhi persyaratan-persyaratan teknis perbankan. Hal ini menyebabkan aspek kelayakan (feasibility) debitur dari usaha skala mikro terabaikan. Dengan demikian, kebutuhan terkait optimalisasi peran dan fungsi perbankan menjadi penting khususnya bagaimana peran dan fungsi tersebut benar-benar dapat memberikan kontribusi nyata dalam peningkatan kuantaitas dan kualtias dari UMKM di Indonesia.

\section{PEMBAHASAN}

Pada prinsipnya, tidak ada model teoritis tunggal yang menjelaskan pembiayaan, khususnya UMKM dapat mempengaruhi kinerja investasi, pertumbuhan dan perkembangan usaha. ${ }^{5}$ Struktur modal yang mendasari teoritis umumnya dapat dijelaskan dalam kerangka teori perdagangan statis oleh Modigliani dan Miller ${ }^{6}$, teori pecking order dari Myers \& Majluf ${ }^{7}$, teori investasi manajerial dari Marris ${ }^{8}$, teori agensi oleh Jensen dan Meckling ${ }^{9}$ dan diperluas oleh Stiglitz dan Weiss ${ }^{10}$. Menurut teori investasi neoklasik (M-M), yang menegaskan sikap pada ketidakrelevanan struktur modal untuk nilai perusahaan, sumber pendanaan internal dan eksternal adalah pengganti yang sempurna. Di dunia yang berfungsi sempurna dari pasar,

${ }^{4}$ Sri Suslilo, Y., Op.Cit.

${ }^{5}$ Qazim Tmava, Florin Peci \& Gazmend Luboteni, "The Role of Banks in Small and Medium Enterprises Financing: A Case Study from Kosovo", International Journal of Economics and Finance, Vol. 5, No. 12, 2013, p. 95.

${ }^{6}$ Modigliani, F., \& Miller, M, "The cost of capital, Corporation Finance and the Theory of Investment", American Economics Review, 48(3), 1958, p. 261-297.

7 Mayers, S. C., \& Majlyf, N. S, "Corporate Finance and Investment Decision: When Firms Have Information that Investors Do Not Have", Journal of Financial Economics, 13(June), 1984, 187-222.

${ }^{8}$ Marris, R, “A Model of the "Managerial” Enterprise", Quarterly Journal of Economics, 72(2), 1963, p. $1-33$.

${ }^{9}$ Jensen, M., \& Meckling. W, "Theory of the firm: Managerial behavior, agency cost and ownership structure", Journal of Financial Economics, 3, 1976, p. 305-360

${ }^{10}$ Stigitz, J. E., \& Weiss, A, "Credit rationing in markets with imperfect information", American Economic Review, 71, 1981, p. 393-410 
pilihan antara pembiayaan melalui modal atau utang tidak relevan. Oleh karena itu, biaya modal dan nilai pasar perusahaan tidak bergantung pada nilai perusahaan. ${ }^{11}$

Pada konteks teori dominan tentang penentuan struktur keuangan perusahaan, dan didasarkan pada premis, bahwa perusahaanlah yang memilih berapa banyak yang akan dibiayai dari utang, dan berapa banyak dari modal, dengan menyeimbangkan biaya keuntungan. Menurut teori ini, tingkat optimal dari struktur modal adalah yang menyamakan laba dan biaya dari utang. Sedangkan menurut teori pecking order, perusahaan pada awalnya lebih menyukai sumber pendanaan internal daripada yang eksternal, dan mengenai sumber eksternal, mereka lebih menyukai hutang terhadap modal. ${ }^{12}$ Dengan demikian, hal ini pada awalnya memiliki penggunaan akumulasi laba, amortisasi, utang, dan, akhirnya, modal ekuitas. Menurut teori ini, perusahaan membiayai kebutuhan investasi mereka berdasarkan urutan hirarkis. Hal ini dapat langsung ke keberadaan asimetri informasi antara manajer (orang dalam) dan investor (orang luar). Sebagai akibatnya, manajer memiliki lebih banyak informasi daripada investor. ${ }^{13}$

Biswajit Bose ${ }^{14}$ dalam hasil penelitiannya menerangkan bahwa tantangan yang dihadapi oleh sektor Usaha Mikro, Kecil dan Menengah (UMKM) timbul dari berbagai faktor. Perusahaan-perusahaan ini kecil dan memiliki kemampuan terbatas untuk menahan guncangan ekonomi. Mereka umumnya berjalan dengan modal yang tidak mencukupi, bahkan sejumlah besar perusahaan bergantung sepenuhnya pada modal pemilik dan pendapatan bisnis, tanpa meminjam dana dari lembaga keuangan. Ini secara alami menghambat potensi mereka untuk mengembangkan bisnis mereka.

Banyak kekhawatiran sektor ini, seperti tingkat teknologi rendah, kurangnya varian produk dan ketidakmampuan untuk meningkatkan tenaga kerja. Adapun persoalan tersebut tidak dapat ditangani tanpa ketersediaan kredit yang memadai dan tepat waktu. Hanya ketika perusahaan ini dibiayai secara memadai, mereka akan dapat berinvestasi dalam menciptakan jaringan distribusi, membangun merek, pengetahuan teknis, penelitian dan pengembangan. Juga, perusahaan-perusahaan ini sering menjadi pemasok perusahaan besar dari masalah realisasi pembayaran untuk produk atau layanan mereka. ${ }^{15}$ Fenomena tersebut memberi tekanan pada modal kerja mereka yang berdampak sangat parah pada operasi mereka. Oleh karena itu, di satu sisi mereka memiliki modal terbatas untuk tetap menjadi aset untuk memperluas operasi mereka. Di sisi lain, karena kurangnya modal kerja yang memadai, mereka merasa sulit untuk melanjutkan operasi mereka yang ada. Kekhawatiran tidak terbatas pada masalah

\footnotetext{
${ }^{11}$ Qazim Tmava, Florin Peci \& Gazmend Luboteni, Op.cit.

12 Ibid.

13 Ibid.

${ }^{14}$ Biswajit Bose, "Financing of Micro, Medium and small scale enterprises in India Key Challenges", Journal of Economics and Finance, Volume 1, Issue 1, 2013, p. 1.

${ }^{15}$ Ibid.
} 
ketersediaan kredit ini, juga tentang biaya kredit. Jika biaya kredit tidak menarik bagi peminjam sektor ini, penyaluran kredit tidak dapat ditingkatkan. ${ }^{16}$

Biswajit Bose ${ }^{17}$ mengemukakan bahwa sektor UMKM sangat membutuhkan lebih banyak modal dengan biaya yang masuk akal. Ketersediaan pendanaan dapat membantu untuk mengatasi beberapa masalah utamanya. Diperlukan lebih banyak modal awal untuk memulai usaha baru. Modal jangka panjang diperlukan untuk membantu perusahaan berinvestasi di bidang infrastruktur dalam hal lahan, pabrik \& permesinan, sumber teknologi dan untuk meningkatkan operasinya. Modal kerja diperlukan untuk membiayai ketidaksesuaian antara utang dan piutang, serta memastikan berjalannya operasi bisnis yang terintegrasi. Dalam menghadapi persaingan tingkat global dan nasional, aliran dana sangat penting untuk kelangsungan hidup dan pertumbuhan UMKM. Tidak hanya perusahaan-perusahaan ini membutuhkan pembiayaan utang, pertumbuhan tidak dapat terjadi tanpa pendanaan ekuitas. Ada peluang bagi perusahaan yang sedang tumbuh mengambil keuangan bank, mendapatkan over-leveraged. Pada saat itu pembiayaan bank lebih lanjut sulit diperoleh. Oleh karena itu, UMKM dapat dikembangkan dengan memiliki akses ke opsi pembiayaan dan pembiayaan ekuitas. ${ }^{18}$ Dengan demikian, UMKM perlu didukung oleh berbagai kebijakan pemerintah yang tentunya bersifat alternatifalternatif pembiayaan.

Berdasarkan hasil penelitian menunjukan bahwa meskipun berbagai inisiatif kebijakan Pemerintah telah dilakukan dalam rangka mendukung peningkatan kuantitas dan kualitas UMKM, nyatanya masih terdapat ketidaksesuaian pasokan dan permintaan dalam ketersediaan keuangan untuk UMKM. Kekurangan kredit yang tepat waktu dan memadai selalu menjadi kendala bagi UMKM. Jangkauan lembaga keuangan formal telah terbatas dalam memberikan layanan perbankan kepada UMKM ini. Ukuran dan pengecualian keuangan berarti bahwa sebagian besar perusahaanperusahaan ini bergantung pada keuangan sendiri dan laba ditahan. Oleh karena itu, pengembangan kapasitas melalui peran dan fungsi perbankan sangat penting bagi UMKM untuk menjadi lebih kompetitif, produktif dan layak.

Penguatan sektor ini tidak dapat terjadi jika UMKM ini tetap kekurangan peluang pembiayaan. Di satu sisi, ada kebutuhan mendesak untuk meningkatkan infrastruktur dasar seperti jalan, listrik dan pasokan air. Di sisi lain, ketersediaan keuangan yang memadai dapat membantu UMKM dalam meningkatkan produk, proses dan teknologi. Perlu dicatat bahwa negara ini melihat bahwa munculnya usaha kecil tapi inovatif, terutama di sektor jasa yang modern dalam pandangan mereka dan mereka membutuhkan bantuan dalam bentuk modal risiko. Perlu fokus yang berkelanjutan

\footnotetext{
16 Ibid.

17 Ibid.

18 Ibid.
} 
pada pengembangan produk pinjaman agar sesuai dengan berbagai persyaratan UMKM mengingat beragamnya usaha yang membentuk sektor ini.

Kontribusi Perbankan dalam meningkatkan UMKM telah menjadi fokus bersama antara sektor pemerintah, perbankan dan pelaku UMKM. Berbagai regulasi dalam rangka mendukung penyaluran pembiayaan kepada UMKM dipermudah melalui perbantuan kebijakan Bank Sentra terhadap perbankan. Persoalan mengemuka ketika peran dan fungsi perbankan terhadap oleh bagaimana prilaku UMKM dalam memenuhi tanggung jawabnya khususnya penggunaan kredit dalam operasionalisasi UMKM. Masalah terjadi ketika NPL menjadikan Perbankan berhati-hati dalam pemberian kredit pada UMKM. Pada konteks tersebut penelitian ini menemukan pentingnya sinergiritas antara seluruh pelaku dalam rangka mengoptimalkan peran dan fungsi perbankan dalam rangka meningkatkan kualtias dan kuantitas UMKM di Indonesia.

Penting untuk meningkatkan tingkat kesadaran tentang UMKM terkait langkahlangkah kebijakan dan langkah-langkah kelembagaan yang bertujuan untuk memfasilitasi aliran kredit ke sektor ini.

\section{Posisi UMKM dalam Ekonomi Nasional}

Peran UMKM dalam pertumbuhan ekonomi dan pembangunan melibatkan lebih dari sekedar peningkatan output dan penghasilan per kapita, di mana dalam skala yang lebih luas, peran UMKM dapat merubah struktur bisnis dan masyarakat. Perubahan ini disertai dengan pertumbuhan dan peningkatan output, yang memungkinkan lebih banyak kekayaan dibagi oleh berbagai UMKM. Menurut teori pertumbuhan ekonomi, Perubahan dan pengembangan difasilitasi oleh inovasi. ${ }^{19}$ Inovasi tidak hanya kunci dalam mengembangkan produk atau proses baru tetapi juga dalam merangsang minat investasi dalam usaha baru yang sedang dibuat. Investasi baru ini bekerja pada sisi permintaan dan penawaran dari persamaan pertumbuhan, di mana modal baru yang diciptakan memperluas kapasitas untuk pertumbuhan (sisi persediaan), dan pengeluaran baru yang dihasilkan menggunakan kapasitas dan output baru (sisi permintaan).

Pengembangan inovasi dan komersialisasi melalui aktivitas kewirausahaan, membantu merangsang menghasilkan pendapatan yang cukup yang mendorong pertumbuhan ekonomi. Demikian pula pada UMKM yang telah memiliki hubungan dengan kemakmuran ekonomi karena mereka berfungsi sebagai sumber penerimaan pajak pemerintah, berkontribusi terhadap produk domestik bruto, penyediaan lapangan kerja, memfasilitasi distribusi barang dan jasa, menyediakan barang dan jasa khusus yang fleksibel. serta melayani sebagai sumber inovasi

\footnotetext{
${ }^{19}$ Daniel Agyapong, "Micro, Small and Medium Enterprises' Activities, Income Level and Poverty Reduction in Ghana - A Synthesis of Related Literature", International Journal of Business and Management, Vol. 5, No. 12; December 2010, p. 199.
} 
industri. ${ }^{20}$ Bank Dunia seperti yang dikemukakan dalam Beck, Demirguc-Kunt \& Levine $^{21}$ mendukung program pengembangan UMKM berdasarkan argumen bahwa UMKM memberikan kontribusi khusus bagi negara berkembang dengan menghasilkan pendapatan yang diperlukan untuk mengurangi kemiskinan.

Dalam ulasannya tentang kontribusi sektor UMKM terhadap pertumbuhan dan perkembangan ekonomi, pentingnya peningkatan sektor untuk pemulihan pertumbuhan ekonomi berkelanjutan, ketenagakerjaan, perdagangan, investasi, dan perkembangan ekonomi yang bersaing secara global, Beck ${ }^{22}$ menemukan bahwa ada hubungan yang kuat dan positif antara ukuran relatif sektor UMKM dan pertumbuhan ekonomi, bahkan ketika mengendalikan faktor penentu pertumbuhan ekonomi lainnya. Namun, hubungan kausal antara ukuran sektor UMK dan pertumbuhan ekonomi tidak kuat setelah mengendalikan bias simultanitas. Pada tingkat agregat, UMKM diyakini menunjukkan pertumbuhan yang mengesankan, terutama bila dibandingkan dengan perusahaan yang lebih besar. Namun, banyak individu UMKM tumbuh perlahan atau tidak sama sekali dalam beberapa kasus, karena keputusan sadar dari pihak pemilik bisnis. ${ }^{23}$

Tidak ada perbedaan terlalu jauh antara UMKM di Indonesia dengan yang terjadi di Dunia secara umum, sektor UMKM kemampuan yang handal dan mumpuni serta memiliki peranan penting dalam kancah perekonomian Nasional. UMKM memiliki proporsi sebesar 99,99\% dari total keseluruhan pelaku usaha di Indonesia atau sebanyak 56,54 juta unit. Usaha Mikro, Kecil, dan Menengah telah mampu membuktikan eksistensinya dalam perekonomian di Indonesia. Ketika badai krisis moneter melanda Indonesia di tahun 1998, usaha berskala kecil dan menengah yang relatif mampu bertahan dibandingkan perusahaan besar. Karena mayoritas usaha berskala kecil tidak terlalu tergantung pada modal besar atau pinjaman dari luar dalam mata uang asing. Sehingga, ketika ada fluktuasi nilai tukar, perusahaan berskala besar yang secara umum selalu berurusan dengan mata uang asing adalah yang paling berpotensi mengalami imbas krisis. ${ }^{24}$

\section{Pembiayaan UMKM oleh Perbankan}

Sebagaimana bank pada umumnya di Indonesia, perbankan menjalankan fungsi bank sebagai tempat menyimpan dan menyalurkan dana dari masyarakat untuk membantu pembangunan di Indonesia termasuk didalamnya dalam pemenuhan

${ }^{20}$ Ibid, p. 199-200.

21 Beck, T., Demirguc-Kunt, A., \& Maksimovic, V, "SMEs, Growth, and poverty - Do pro-SME policies work?”, World Bank Policy Research Working Paper No. 268, 2004.

22 Ibid.

23 Nichter, S., \& Goldmark, L, Understanding micro and small enterprise growth, Accelerated Microenterprise Advancement Project: USAID, 2005.

${ }^{24}$ Bank Indonesia, Profile Bisnis UMKM, Jakarta: LPPI, 2015, hlm 5. 
pembiayan UMKM. Eksistensi suatu bank juga sangat tergantung pada kepercayaan UMKM tersebut, di mana semakin tinggi kepercayaan, semakin tinggi pula kesadaran untuk menyimpan uangnya ke bank dan menggunakan jasajasa lain dari bank, selain tergantung pada keahlian pengelolaanya, juga tergantung pada integritas. Sebagai konsekuensi nyata dari salah satu tugas pokok perbankan ialah mendorong kelancaran produksi dan pembangunan serta memperluas kesempatan kerja guna meningkatkan taraf hidup rakyat. Lebih khusus lagi fungsi bank pada umumnya sebagai lembaga keuangan adalah: ${ }^{25}$

1. Menghimpun dana dari masyarakat dalam bentuk simpanan;

2. Menyalurkan dana ke masyarakat dalam bentuk pinjaman;

3. Memperlancar transaksi perdagangan dan peredaran uang.

Pada dasarnya, fungsi perbankan yang paling pokok baik konvensional maupun syariah adalah sebagai lembaga intermediary, yaitu menampung pihak-pihak yang kelebihan dana untuk nantinya disalurkan kepada pihak-pihak yang membutuhkan dana. Fungsi inilah yang juga dilakukan oleh perbankan dalam membantu menyalurkan dana untuk usaha kecil dan menengah.

Berdasarkan data yang dirilis Bank Indonesia, pertumbuhan kredit pada triwulan IV 2017 terjadi pada klasifikasi usaha kredit UMKM sebesar 12.2\% (yoy), $10.9 \%$ (yoy) dan 8,3\% dibandingkan pertumbuhan triwulan sebelumnya sebesar 9.9\% (yoy), 9,3 (yoy) dan 6.9\%. Selanjutnya pangsa pasar kredit UMKM terhadap total kredit perbankan pada perideo laporan sebesar $20 \%$, telatif sama dari pangsa triwulan sebelumnya. Sedangkan Bank Indonesa juga merilis klasifikasi usaha dimana sebagian besar kredit UMKM disalurkan pada usaha mengeah 45\%,4 dan selebihnya kepada kerdit usaha kecil 24.8\% dan kredit usaha mikro sebesar $29.9 \%$. Pemberian kredit oleh perbankan digunakan UMKM untuk mebiayai kredit modal kerja sebesar $74,5 \%$, sedangkan untuk redit investasi tercatat $25,5 \%$. Sedangkan menurut kelompok Bank, kredit UMKM sebagian disalurkan oleh:

\section{Tabel 2 Penyaluran Kredit dalam Kelompok Bank di Indonesia}

\begin{tabular}{|l|l|l|}
\hline Kelompok Bank & Persentase & Jumlah \\
\hline Bank Persero & $50,4 \%$ & 449,0 triliun \\
\hline Bank Swasta Nasional Devisa & $32,6 \%$ & 322,9 triliun \\
\hline Bank Pemerintah Daerah & $7,6 \%$ & 74,9 triliun \\
\hline BPR/BPRS & $4,8 \%$ & 47,9 triliun \\
\hline
\end{tabular}

${ }^{25}$ Muhammad, Lembaga-Lembaga Kontemporer, Yogyakarta: UII Press, 2000, hlm. 122 


\begin{tabular}{|l|l|l|}
\hline Bank Swasta Nasional non Devisa & $3,9 \%$ & 38,1 triliun \\
\hline Bank Campuran & $0,7 \%$ & 6,4 triliun \\
\hline Bank Asing & 0,1 & 763 miliar \\
\hline
\end{tabular}

Sumber: Departemen Pengembangan UMKM Bank Indonesia.

Selanjutnya berdasarkan data dari Bank Indonesia, sektor ekonomi penyaluran kredit perbankan kepada UMKM masih didominasi oleh sektor perdagangan besar dan eceran, industri pengolahan dan sektor pertanian, perburuan dna kehutanan masingmasing sebesar $51,1 \%, 9,9 \%$ dan $8,9 \%$. Sedangkan dalam hal lokasi proyek UMKM, DKI Jakrta merupakan provinsi dengan pemberian kredit UMKM terbesar yaitu sebesar RP. 143,9 triliun (14,5), diikuti Jawa Timur Rp. 136,9 triliun dan Jawa Barat Rp. 133,6 triliun (13,5\%). Persoalan mengemuka ketika pertumbuhan kredit tersebut diiringi juga kenaikan NPL UMKM yaitu mencapai 4,35\%. Adapun NPL tertinggi terjadi pada kredit usaha menegah sebesar $5.16 \%$ dan terrendah terjadi pada kredit usaha mikro sebesar $2.82 \%$. Sedangkan NPL kredit usaha kecil tercatat sebesar $4.38 \% .^{26}$

Temuan penelitian menunjukan bahwa UMKM akan tetap mampu tumbuh dan berkembang. Namun di sisi lain, jika diperhatikan lebih seksama maka kelemahan UMKM adalah tidak akan bisa mengembangkan usahanya jika tidak mendapatkan kucuran bantuan modal dalam berkompetisi, maka kelemahan ini seperti kurangnya permodalan, kemampuan manajerial persaingan yang kurang sehat mengakibatkan ruang lingkup usaha menjadi terbatas sulit dalam jangka pendek terselasaikan walaupun pemerintah mengerahkan kebijakan-kebijakan dalam mendukung UMKM. Persoalannya, bukan saja pada standar ganda Perbankan terhadap UMKM, melainkan stigma ini terbangun melalui tingginya NPL dari sektor UMKM yang tentunya bukan saja dapat mempengaruhi kinerja keuangan perbankan namun juga citra perbankan terhadap hasil usaha kerjanya.

\section{KESIMPULAN}

Usaha sektor mikro, kecil dan menengah memiliki peran penting dalam pertumbuhan ekonomi negara berkembang seperti Indonesia. UMKM memainkan peran katalis dalam pengembangan kegiatan industri dan komersial. Dalam rantai nilai keseluruhan dari berbagai industri, UMKM ini ditempatkan di posisi-posisi penting. Oleh karena itu, penting untuk fokus pada isu-isu yang berdampak pada penciptaan, kelangsungan hidup dan pertumbuhan usaha di sektor ini. Salah satu masalah utama adalah

${ }^{26}$ Departemen Pengembangan UMKM Bank Indonesia, Laporan Perkembangan Kredit UMKM Triwulan IV, Jakarta: BI, 2018, hlm 1-2. 
kebutuhan kredit oleh perusahaan-perusahaan ini yang sejauh ini masih belum optimal.

Kebutuhan perhatian yang lebih besar pada kebutuhan pembiayaan sektor UMKM menjadi urgensi terkait potensi besar yang dimiliki UMKM. Usaha ini membutuhkan bantuan kredit dari perbankan pada berbagai tahap siklus hidup mereka. Karakteristik unik dari jenis usaha ini menyiratkan bahwa kebutuhan kredit mereka layak mendapat perhatian yang terfokus. Oleh karena itu, bank dan lembaga keuangan lainnya memiliki tanggung jawab untuk menawarkan produk kredit dan skema pembiayaan yang memenuhi persyaratan sektor UMKM. Dalam memenuhi persyaratan pembiayaan ini, masalah mungkin timbul sehubungan dengan kualitas aset lembaga keuangan. Untuk mempromosikan sektor ini, ada kebutuhan untuk menciptakan lingkungan yang memungkinkan yang dapat memastikan aliran kredit dan pada saat yang sama mengatasi kekhawatiran tentang manajemen kredit yang dibuat untuk sektor ini.

\section{DAFTAR PUSTAKA}

\section{Buku}

Bank Indonesia, Profile Bisnis UMKM, Jakarta: LPPI, 2015.

Departemen Pengembangan UMKM Bank Indonesia, Laporan Perkembangan Kredit UMKM Triwulan IV, Jakarta: BI, 2018.

Muhammad, Lembaga-Lembaga Kontemporer, Yogyakarta: UII Press, 2000.

Nichter, S., \& Goldmark, L. Understanding micro and small enterprise growth, Accelerated Microenterprise Advancement Project: USAID, 2005

\section{Jurnal}

Beck, T., Demirguc-Kunt, A., \& Maksimovic, V, "SMEs, Growth, and poverty - Do pro-SME policies work?", World Bank Policy Research Working Paper No. 268, 2004.

Biswajit Bose, "Financing of Micro, medium and small scale enterprises in India Key Challenges", Journal of Economics and Finance, Volume 1, Issue 1, 2013.

Daniel Agyapong, "Micro, Small and Medium Enterprises' Activities, Income Level and Poverty Reduction in Ghana - A Synthesis of Related Literature", International Journal of Business and Management Vol. 5, No. 12; December 2010.

Jensen, M., \& Meckling, W, “Theory of the firm: Managerial behavior, agency cost and ownership structure", Journal of Financial Economics, 3, 1976.

Marris, R, "A Model of the "Managerial" enterprise", Quarterly Journal of Economics, 72(2), 1963. 
Mayers, S. C., \& Majlyf, N. S, "Corporate finance and investment decision: When firms have information that investors do not have", Journal of Financial Economics, 13(June), 1984.

Modigliani, F., \& Miller, M, "The cost of capital, corporation finance and the theory of investment”, American Economics Review, 48(3), 1958.

Qazim Tmava, Florin Peci \& Gazmend Luboteni, "The Role of Banks in Small and Medium Enterprises Financing: A Case Study from Kosovo”, International Journal of Economics and Finance, Vol. 5, No. 12, 2013.

Sri Susilo, Y. \& Sutarta, A.E, "Masalah dan Dinamika Industri Kecil Pasca Krisis Ekonomi”, Jurnal Ekonomi Pembangunan, Vol. 9 No. 1, 2004.

Sri Suslilo, Y, "Peran Perbankan Dalam Pembiayaan Umkm di Provinsi DIY", Jurnal Keuangan dan Perbankan, Vol. 14, No. 3 September 2010.

Stigitz, J. E., \& Weiss, A, "Credit rationing in markets with imperfect information", American Economic Review, 71, 1981, 393-410

Yuli Rahmini Suci, "Perkembangan UMKM (Usaha Mikro Kecil Dan Menengah) di Indonesia", Jurnal Ilmiah Cano Ekonomos, Vol. 6 No. 1 Januari 2017. 